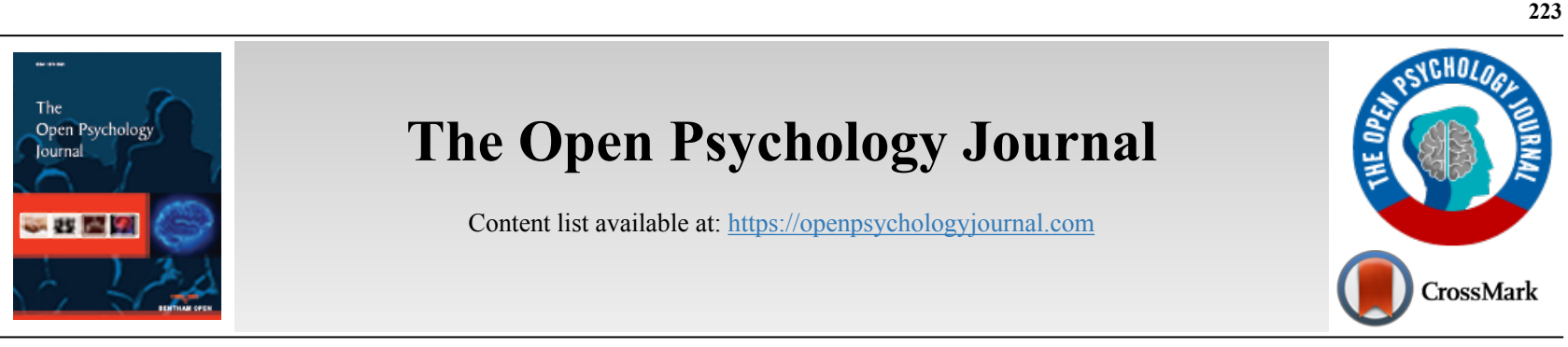

RESEARCH ARTICLE

\title{
Selfie Behaviors and Personality Traits: More than Meets the Eye
}

\author{
Alexandra M. Mihailescu, ${ }^{1, *}$ \\ ${ }^{1}$ Faculty of Psychology, Titu Maiorescu University, Bucharest, Romania
}

\begin{abstract}
:
Background:

Selfies are a rising phenomenon associated with the widespread use of smartphones and social media. The objective of this study was to evaluate the relationship between different personality traits and selfie behaviors.

Methods:

Undergraduate psychology students were asked to complete a questionnaire about their frequency of selfie taking, selfie posting to social media, and selfie sharing through private messaging. They were also asked to complete the Rosenberg 10-item self-esteem scale and the International Personality Item Pool (IPIP)-50 item scale to evaluate the Big Five personality traits.

\section{Results:}

A total of 96 participants were included in this study (mean age \pm standard deviation of $26.4 \pm 9.0$ years, $81.3 \%$ women). On univariate analysis there was a significant negative correlation between the frequency of selfie taking (Spearman $r=-0.228, p=0.025)$ or posting $($ Spearman $r=$ $-0.238, p=0.025)$ and emotional stability. However, on multivariate linear regression analysis adjusting for age among other factors, only selfesteem was independently and negatively correlated with the frequency of selfie taking $($ beta $=-0.206, p=0.020)$ or posting $($ beta $=-0.233$, $p=$ $0.020)$, with the effect most notable in young $(<25$ years) individuals for selfie taking. Extraversion was independently and positively correlated with the frequency of selfie sharing (beta $=0.264, \mathrm{p}=0.005)$, with the effect most notable in young $(<25$ years) women.

\section{Conclusion:}

Findings from this study further expand our knowledge of the relationship between different personality traits and rising digital media phenomena.
\end{abstract}

Keywords: Smartphones, Social media, Big five, Self-esteem, Personality traits, Selfie posting.

\begin{tabular}{|l|l|l|l|}
\hline Article History & Received: February 29, 2020 & Revised: May 20, 2020 & Accepted: June 10, 2020
\end{tabular}

\section{INTRODUCTION}

The use of smartphones and other personal digital devices has become a new global epidemic, especially since they are becoming increasingly available and affordable. Use is no longer restricted to a certain age group but spans the whole age spectrum and affects all genders. In one study from 2016 involving 30,677 participants from Europe, it was found that individuals spend approximately 2.5 hours per day on their smartphone, for various activities, including communication, social media interaction, and photo/video utilization [1]. More recent statistics available from smartphone utilization apps (2020) reported that, globally, individuals spend, on average 3 hours and 15 minutes on their smartphone $(20 \%$ spend an ex-

\footnotetext{
* Address correspondence to this author at the Faculty of Psychology, Titu Maiorescu University, 22 Strada Dâmbovnicului Tineretului, Bucharest 040441, Romania; Tel: +40720507905; E-mail: alexandra.m523@yahoo.com
}

cess of 4.5 hours) and that most people check their phones 58 times a day [2].

A "selfie" is a self-photograph, usually taken by a smartphone or other personal digital devices that may be posted or shared with others through social media and communication platforms. In recent years, selfie taking became a prevalent and global phenomenon that in 2013, "selfie" was voted as word of the year by the Oxford dictionary [3]. As with other aspects of digital and social media, several investigators grew interested in determining the link between selfie behaviors and different personality traits. The bulk of research has been mostly focused on narcissism. Narcissism was positively correlated with selfie taking frequency in some studies [4], while it was negatively correlated in others [5], and not correlated at all in yet other studies [6]. A positive correlation was also found between narcissism and the 
frequency of selfie posting to social media [3, 7, 8], although some studies found the observation to be only applicable in men $[9,10]$.

Studies looking into the relationship between other personality traits and selfie behaviors are limited or restricted to 'travel' selfies $[6,11]$. In one study by Etgar and AmichaiHamburger [6], the relationship between the frequency of selfie taking and self-esteem or the Big Five traits was evaluated (extraversion, agreeableness, conscientiousness, emotional stability, and openness to experiences). However, the authors did not evaluate the relationship between such personality traits and the frequency of selfie posting to social media or sharing through communication platforms; and their methodology of questioning about selfie taking did not fully make that distinction. The act of selfie taking and the acts of selfie posting or sharing may be reflecting different human behaviors. It is clear from earlier studies that most selfies individuals take do not actually end up being posted on social media because of self-appearance worries and ideas about privacy [12]; thus, it remains imperative to conduct research that clearly distinguishes these two different acts and their association with personality traits.

With this background, the aim of this study is to evaluate the relationship between different personality traits (selfesteem and the Big Five) and the frequency of selfie taking, as well as selfie posting to social media and sharing through private messaging. Such evaluation will help distinguish if different personality traits are associated with different selfie behaviors and will address the current knowledge gaps. Effects of age and gender on such relationships will also be evaluated.

\section{MATERIALS AND METHODS}

This was a cross-sectional study of undergraduate first year psychology students attending a private university in Bucharest, Romania. All students attending the university during one calendar week were approached between classes, and all attendees agreed to participate in the study. The questionnaire captured data on demographics, selfie behaviors, self-esteem, and the Big Five personality traits. The study was conducted in accordance with the standards of the Declaration of Helsinki (1983) and was approved by the Ethical Committee of the Department of Psychology at Titu Maiorescu University. All participants provided written informed consent prior to participation.

\subsection{Selfie Behaviors}

Participants answered the following questions to determine their selfie behavior (English translation provided): Q1. How often do you take selfies? (Once a day, Every couple of days, Once a week, Less than once a week, Never); Q2. What are you most likely to do first with the selfie after taking it? (Keep it for yourself, Post it on social media, Share it with friends through private messages, None); Q3. How often do you post selfies on social media (e.g. Instagram, Facebook)? (Once a day, Every couple of days, Once a week, Less than once a week, Never). Q4. How often do you check the number of likes your Selfie received shortly after posting on social media? (A couple of times per hour, Every hour, A couple of times per day, Once a day or less, Never); Q5. How often do you share Selfies with friends through private messages (e.g. WhatsApp, Messenger)? (Once a day, Every couple of days, Once a week, Less than once a week, Never).

Questions 1 (selfie taking), 3 (selfie posting to social media), 4 (Checking for selfie likes shortly after posting to social media) and 5 (selfie sharing with friends through private messages) requested answers on a 5-point Likert scale to reflect the frequency of the specific behavior, as guided by earlier studies [6]. Question 2 was mainly used to determine the most common type of active participants are likely to do after taking a selfie.

\subsection{Self-esteem}

Self-esteem was measured using the Rosenberg [13] selfreport, self-esteem scale, which contains 10 items on a 4-point Likert scale ranging from "strongly agree" to "strongly disagree". After reversing the scores for specific items, the sum of scores for all ten items indicates the Total Score. A higher Total Score indicates more self-esteem. Validated Romanian translation was used [14]. The test had good internal reliablity (Cronbach's alpha: 0.752) in this study.

\subsection{Big Five}

The Big Five personality traits (extraversion, agreeableness, conscientiousness, emotional stability, openness to experiences) were measured using the International Personality Item Pool (IPIP)-50 scale developed by Goldberg [15], which contains 50 items (10 reflecting each of the five personality traits) on a 5-point Likert scale ranging from "totally disagree" to "totally agree". After reversing the scores for specific items, the sum of scores for all ten items indicates the Total Score of the specific personality trait. A higher Total Score indicates more extraversion, agreeableness, conscientiousness, emotional stability, or openness to experiences. Romanian translation was used based on a Romanian validation study [16]. The test had good internal reliability (Cronbach's alpha: 0.878 for extraversion, 0.792 for agreeableness, 0.809 for conscientiousness, 0.787 for emotional stability, and 0.780 for openness to experiences) in this study.

\subsection{Statistical Analysis}

Data coding was carried out for the ordinal variables of selfie taking behavior related questions. Total scores for selfesteem and each of the Big Five personality traits were calculated after the reversal of respective items. Age was also transformed into an additional nominal variable ( $>25$ and $\leq 25$ years) split around the rounded mean of the sample, in view of a high proportion of participants in this study that fall outside the standard undergraduate student age range reported in other studies.

Descriptive statistics were provided as mean \pm standard deviation, median (minimum and maximum) or percentages. Bivariate correlations were conducted using Spearman's correlation coefficient or the Cramer's V test. Multivariate linear regression analysis was also used in a step-wise manner, to determine the association between several independent 
variables of interest (age, gender, and the personality traits) and each of the dependent variables of selfie behaviors (selfie taking, selfie posting, selfie likes, selfie sharing). All p-values were two-sided with the level of significance set at $<0.05$.

\section{RESULTS}

\subsection{Participants}

A total of 96 participants were included in this study. Their mean age \pm standard deviation was $26.4 \pm 9.0$ years (range: $18-53$ years) and the median age was 21 years. A total of 56 (58.3\%) participants were $\leq 25$ years of age, while $40(41.7 \%)$ were older than 25 years. Participants included $78(81.3 \%)$ women and $18(18.3 \%)$ men.

\subsection{Selfie Taking}

Only $8(8.3 \%)$ participants reported never taking a selfie. The remaining $88(91.7 \%)$ participants reported taking selfies at different frequencies (Fig. 1A).

\subsection{Selfie Posting and Sharing}

Among those 88 participants who reported taking selfies,

(A) Selfie taking

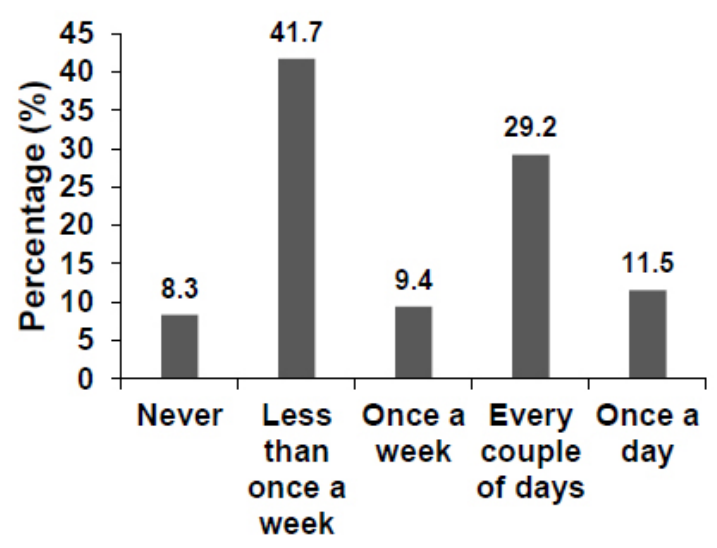

(C) Checking for selfie likes shortly after posting to social media

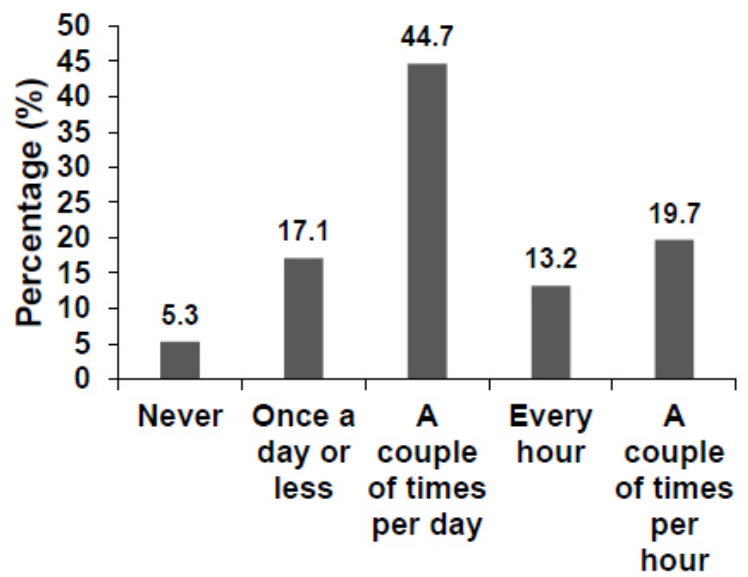

they reported the following when asked what they are most likely to do first with the selfie after taking it: 33 (37.5\%) keep the selfies for themselves, $22(25.0 \%)$ post the selfies on social media, $31(35.2 \%)$ share the selfies with friends through private messages, while $2(2.3 \%)$ do not do any of the aforementioned.

Among the 88 participants who reported taking selfies, 12 $(13.6 \%)$ reported never posting their selfies to social media (e.g. Instagram or Facebook). The remaining 76 (86.4\%) participants reported posting selfies to social media at different frequencies (Fig. 1B). Among the 76 participants who reported posting their selfies to social media, 4 (5.3\%) reported never checking the number of likes their selfie received shortly after posting. The remaining $72(94.7 \%)$ participants reported checking the number of likes their selfie received shortly after posting at different frequencies (Fig. 1C). Among the 88 participants who reported taking selfies, 10 (11.4\%) reported never sharing their selfies with friends through private messages (e.g. WhatsApp or Messenger). The remaining 78 $(88.6 \%)$ participants reported sharing their selfies with friends through private messages at different frequencies (Fig. 1D).

(B) Selfie posting to social media

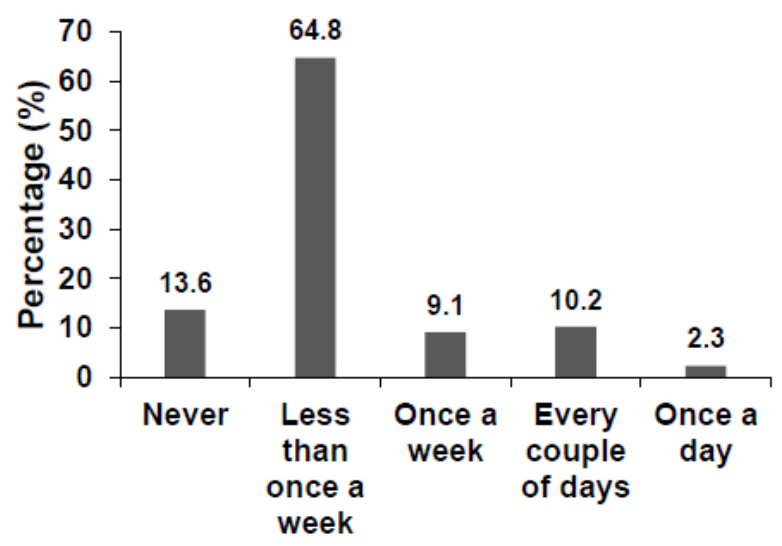

(D) Selfie sharing with friends through private messages

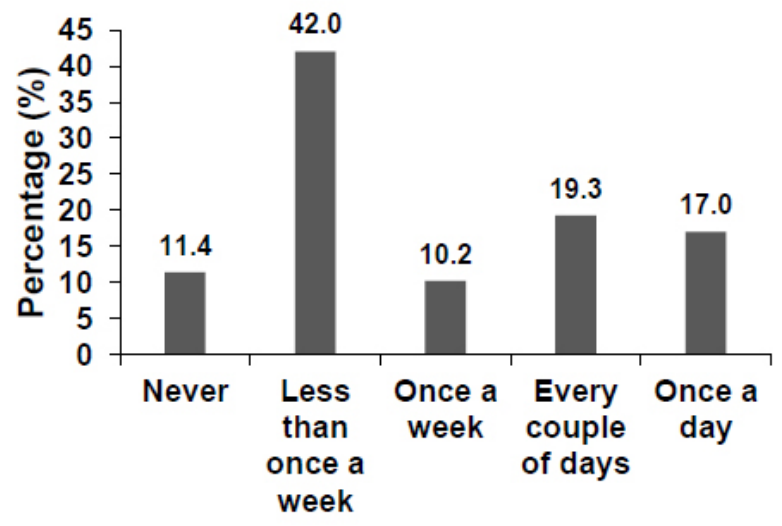

Fig. (1). Frequency for (A) selfie taking $(n=96)$; (B) selfie posting to social media $(n=88)$; (C) checking for selfie likes shortly after posting to social media $(\mathrm{n}=76)$; (D) selfie sharing with friends through private messages $(\mathrm{n}=88)$. 
(A) Selfie taking

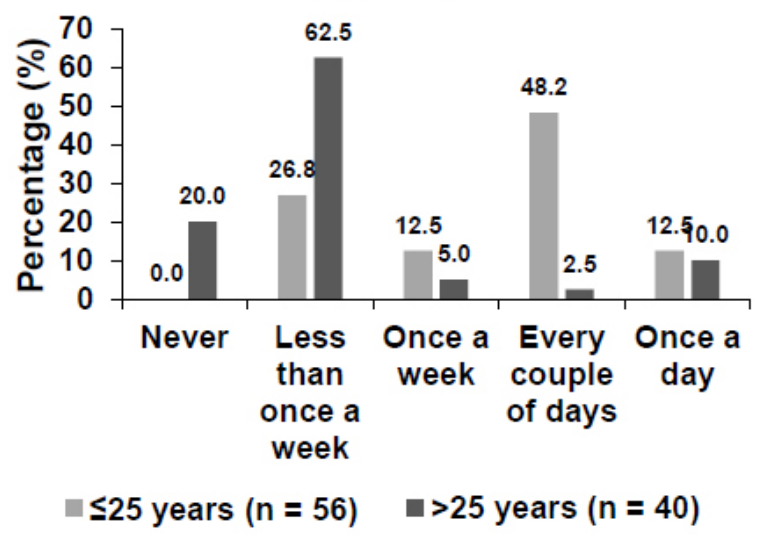

(C) Checking for selfie likes shortly after posting to social media

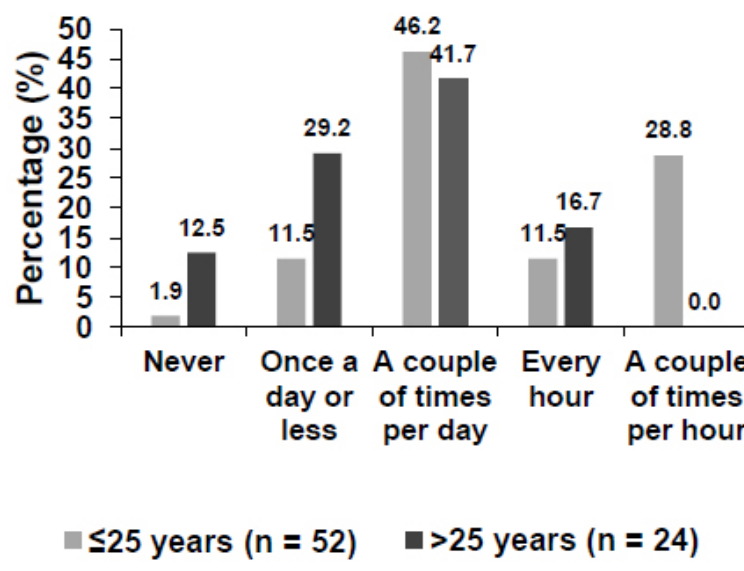

(B) Selfie posting to social media

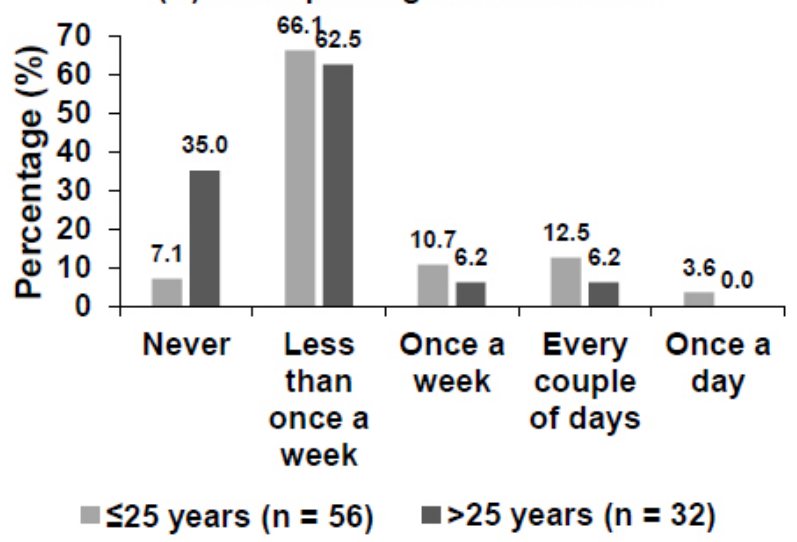

(D) Selfie sharing with friends through private messages

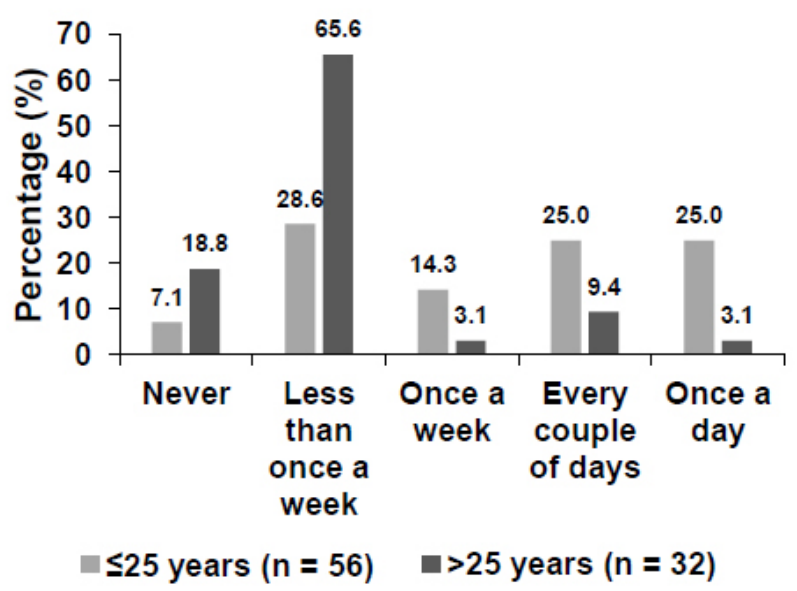

Fig. (2). Frequency according to age $\leq 25$ or $>25$ years for (A) selfie taking $(n=96)$; (B) selfie posting on social media $(n=88)$; (C) checking the number of likes their selfie received shortly after posting on social media $(n=76)$; (D) selfie sharing with friends through private messages $(n=88)$.

\subsection{Age and Gender vs. Selfie Behaviors}

There was a significant and negative correlation between selfie taking frequency and age (Spearman's $r=-0.531, \mathrm{p}$ $<0.001)$. The distribution of selfie taking frequencies in participants $\leq 25$ years and $>25$ years of age is illustrated in Fig. (2A). Among those 88 participants who reported taking selfies, there was a significant and negative correlation between reported frequency of selfie posting on social media and age (Spearman's $r=-0.341, p<0.001$ ). The distribution of frequency of selfie posting on social media in participants $\leq 25$ years and $>25$ years of age is illustrated in Fig. (2B). Among those 76 participants who reported posting selfies to social media, there was a significant and negative correlation between reported frequency of checking the number of likes their selfie received shortly after posting and age (Spearman's $r=-0.299$, $p=0.009$ ). The distribution of frequency of checking the number of likes their selfie received shortly after posting in participants $\leq 25$ years and $>25$ years of age is illustrated in Fig. (2C). Among those 88 participants who reported taking selfies, there was a significant and negative correlation between reported frequency of selfie sharing with friends through private messages and age (Spearman's $r=-0.511, \mathrm{p}<0.001$ ). The distribution of frequency of selfie sharing with friends through private messages in participants $\leq 25$ years and $>25$ years of age is illustrated in Fig. (2D).

There was no statistically significant association between participants' gender and the reported frequency of selfie taking ( $\mathrm{n}=96$, Cramer's V, $\mathrm{p}=0.148$ ), selfie posting to social media $(\mathrm{n}=88$, Cramer's V, $\mathrm{p}=0.066)$, checking the number of likes their selfie received shortly after posting on social media $(\mathrm{n}=76$, Cramer's V, $\mathrm{p}=0.286$ ), or selfie sharing with friends through private messages $(n=88$, Cramer's V, $p=0.069)$ (Fig. 3).

\subsection{Personality Traits}

Scores for the different personality traits among the study participants are summarized in Table $\mathbf{1}$. There was a significant and positive correlation between age and emotional stability (Spearman's $r=0.252, p=0.013$ ) but not with any of the other personality traits. There was no statistically significant correlation between gender and any of the personality traits (Table 2). 


\section{(A) Selfie taking}

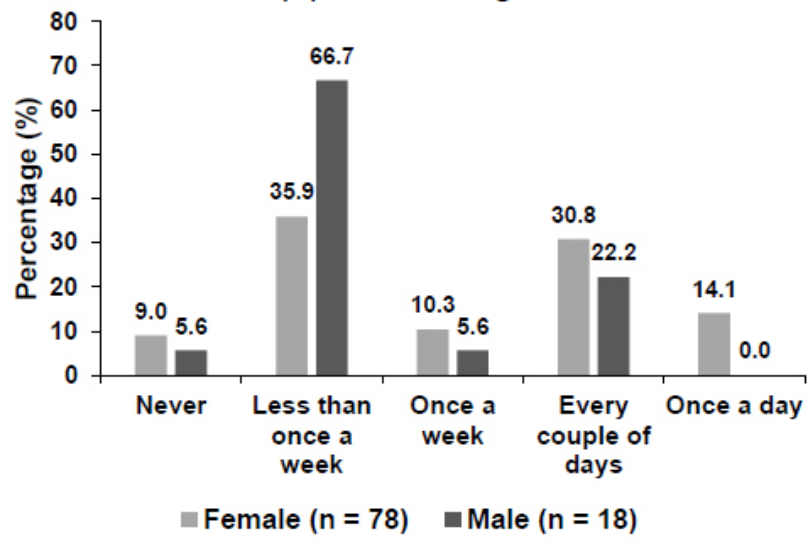

(C) Checking for selfie likes shortly after posting to social media

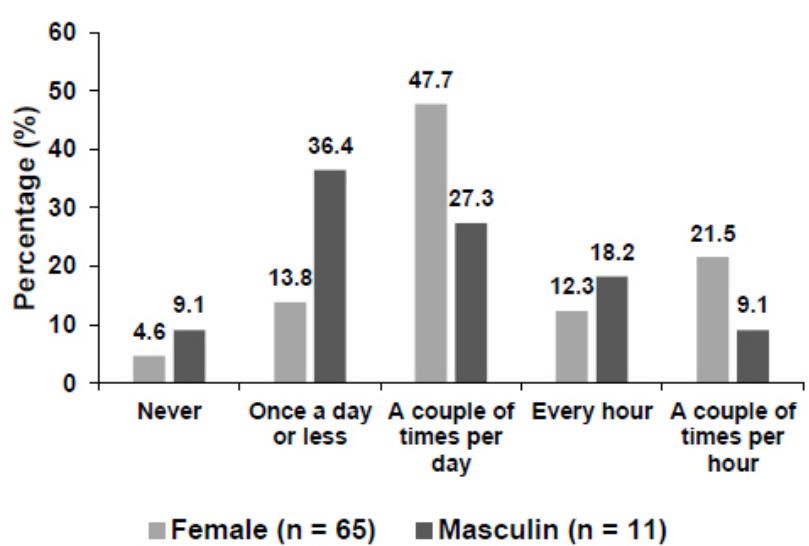

(B) Selfie posting to social media

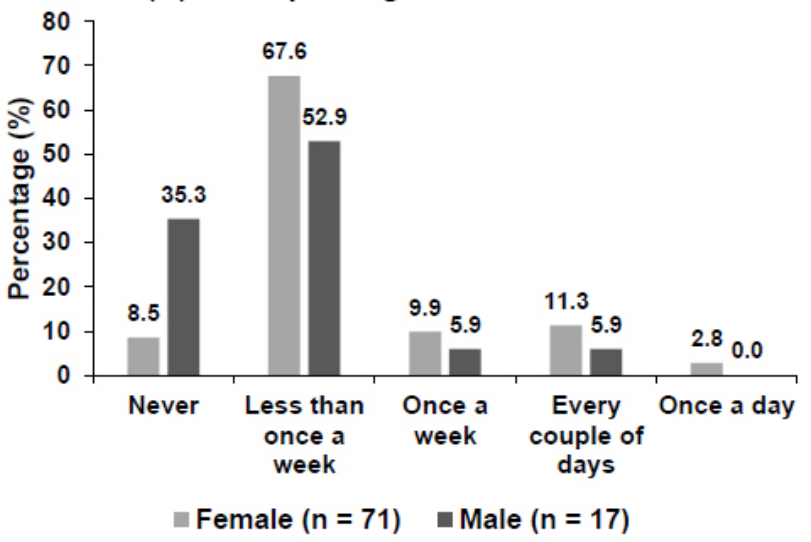

(D) Selfie sharing with friends through private messages

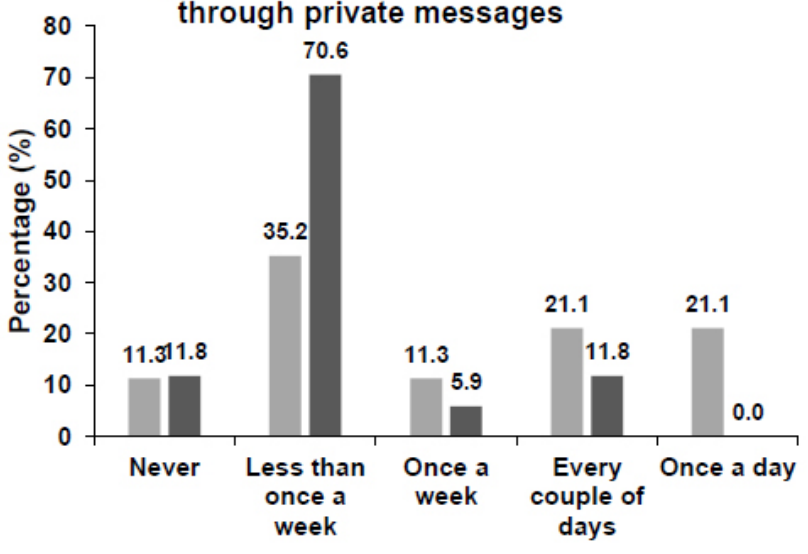

Female $(\mathrm{n}=71) \quad$ Male $(\mathrm{n}=17)$

Fig. (3). Frequency according to gender for $(\mathbf{A})$ selfie taking $(n=96)$; (B) selfie posting on social media $(n=88)$; (C) checking the number of likes their selfie received shortly after posting on social media $(n=76)$; $(D)$ selfie sharing with friends through private messages $(n=88)$.

Table 1. Personality traits of the study participants $(n=96)$.

\begin{tabular}{|c|c|c|c|c|}
\hline Personality Trait & Mean \pm SD & Median & Minimum & Maximum \\
\hline Self-esteem & $19.8 \pm 4.1$ & 19 & 13 & 29 \\
\hline Extraversion & $34.5 \pm 7.9$ & 35 & 10 & 50 \\
\hline Agreeableness & $40.6 \pm 5.7$ & 41 & 14 & 49 \\
\hline Conscientiousness & $35.8 \pm 6.8$ & 36 & 18 & 48 \\
\hline Emotional stability & $28.8 \pm 6.7$ & 29 & 10 & 43 \\
\hline Openness to experiences & $38.67 \pm 5.6$ & 39 & 16 & 50 \\
\hline
\end{tabular}

SD, standard deviation.

Table 2. Correlations by Spearman's correlation coefficient between personality traits, age, and gender of the study participants $(n=96)$.

\begin{tabular}{|c|c|c|c|c|c|c|c|c|}
\hline- & Age & Gender & Self-Esteem & Extraversion & Agreeableness & Conscientiousness & $\begin{array}{c}\text { Emotional } \\
\text { Stability }\end{array}$ & $\begin{array}{c}\text { Openness to } \\
\text { Experiences }\end{array}$ \\
\hline Age & - & - & - & - & - & - & - & - \\
\hline Gender & $\begin{array}{c}\mathrm{r}=0.250 \\
\mathbf{p}=\mathbf{0 . 0 1 4}\end{array}$ & - & - & - & - & - & - & - \\
\hline Self-esteem & $\begin{array}{c}\mathrm{r}=-0.091 \\
\mathrm{p}=0.376\end{array}$ & $\begin{array}{c}\mathrm{r}=-0.057 \\
\mathrm{p}=0.584\end{array}$ & - & - & - & - & - & - \\
\hline
\end{tabular}




\begin{tabular}{|c|c|c|c|c|c|c|c|c|}
\hline- & Age & Gender & Self-Esteem & Extraversion & Agreeableness & Conscientiousness & $\begin{array}{c}\text { Emotional } \\
\text { Stability }\end{array}$ & $\begin{array}{l}\text { Openness to } \\
\text { Experiences }\end{array}$ \\
\hline Extraversion & $\begin{array}{l}r=0.004 \\
p=0.970\end{array}$ & $\begin{array}{l}r=0.081 \\
p=0.435\end{array}$ & $\begin{array}{c}r=-0.361 \\
\mathbf{p}<\mathbf{0 . 0 0 1}\end{array}$ & - & - & - & - & - \\
\hline Agreeableness & $\begin{array}{l}r=0.017 \\
p=0.866\end{array}$ & $\begin{array}{l}\mathrm{r}=-0.132 \\
\mathrm{p}=0.201\end{array}$ & $\begin{array}{c}r=-0.365 \\
\mathbf{p}<\mathbf{0 . 0 0 1}\end{array}$ & $\begin{array}{l}r=0.368 \\
\mathbf{p}<\mathbf{0 . 0 0 1}\end{array}$ & - & - & - & - \\
\hline Conscientiousness & $\begin{array}{l}\mathrm{r}=0.157 \\
\mathrm{p}=0.125\end{array}$ & $\begin{array}{l}\mathrm{r}=0.016 \\
\mathrm{p}=0.878\end{array}$ & $\begin{array}{c}r=-0.380 \\
\mathbf{p}<\mathbf{0 . 0 0 1}\end{array}$ & $\begin{array}{l}r=0.265 \\
\mathbf{p}=\mathbf{0 . 0 0 9}\end{array}$ & $\begin{array}{l}r=0.315 \\
\mathbf{p}=\mathbf{0 . 0 0 2}\end{array}$ & - & - & - \\
\hline Emotional stability & $\begin{array}{l}r=0.252 \\
\mathbf{p}=\mathbf{0 . 0 1 3}\end{array}$ & $\begin{array}{l}r=0.082 \\
p=0.425\end{array}$ & $\begin{array}{l}r=-0.274 \\
\mathbf{p}=\mathbf{0 . 0 0 7}\end{array}$ & $\begin{array}{l}r=0.200 \\
\mathbf{p}=\mathbf{0 . 0 1 5}\end{array}$ & $\begin{array}{l}r=0.329 \\
\mathbf{p}=\mathbf{0 . 0 0 1}\end{array}$ & $\begin{array}{l}r=0.416 \\
\mathbf{p}<\mathbf{0 . 0 0 1}\end{array}$ & - & - \\
\hline Openness to experiences & $\begin{array}{c}r=-0.013 \\
p=0.900\end{array}$ & $\begin{array}{l}\mathrm{r}=0.086 \\
\mathrm{p}=0.407\end{array}$ & $\begin{array}{l}r=-0.259 \\
\mathbf{p}=\mathbf{0 . 0 1 1}\end{array}$ & $\begin{array}{l}r=0.325 \\
\mathbf{p}=\mathbf{0 . 0 0 1}\end{array}$ & $\begin{array}{l}r=0.366 \\
\mathbf{p}<\mathbf{0 . 0 0 1}\end{array}$ & $\begin{array}{l}\mathrm{r}=0.136 \\
\mathrm{p}=0.186\end{array}$ & $\begin{array}{l}r=0.036 \\
p=0.726\end{array}$ & - \\
\hline
\end{tabular}

\subsection{Personality Traits vs. Selfie Behaviors}

There was a significant negative correlation between the reported frequency of selfie taking and emotional stability (Spearman's $\mathrm{r}=-0.228, \mathrm{p}=0.025$ ). There were no other significant correlations between the remaining personality traits and the reported frequency of selfie taking. Similarly, there was a significant negative correlation between the reported frequency of selfie posting to social medial and emotional stability (Spearman's $r=-0.238, p=0.025$ ) while there were no other significant correlations between the remaining personality traits and the reported frequency of selfie posting to social medial. There was a significant positive correlation between the reported frequency of selfie sharing with friends through private messages and extraversion (Spearman's $r=$ $0.218, p=0.042$ ). There were no other significant correlations between the remaining personality traits and the reported frequency of selfie sharing with friends through private messages. None of the personality traits correlated with the reported frequency of checking the number of likes their selfie received shortly after posting (Table $\mathbf{3}$ ).

\subsection{Personality Traits vs. Selfie Behaviors Stratified According to Age and Gender}

In participants $\leq 25$ years of age, there was a significant negative correlation between the reported frequency of selfie taking and self-esteem (Spearman's $r=-0.347, p=0.009$ ). There was also a significant positive correlation between the reported frequency of selfie sharing with friends through private messages and extraversion (Spearman's $\mathrm{r}=0.347, \mathrm{p}=$ 0.004 ) as well as agreeableness (Spearman's $r=-0.363, p=$ 0.006 ). In participants $>25$ years of age, there was a significant negative correlation between the reported frequency of selfie sharing with friends through private messages and emotional stability (Spearman's $r=-0.521, p=0.002$ ). The remaining correlations did not reach statistical significance, although there was a trend towards a correlation between the reported frequency of selfie taking and emotional stability in participants $>25$ years of age (Table 4).

When stratified according to gender, the only statistically significant correlations were a negative correlation between the reported frequency of selfie posting to social media and emotional stability in men (Spearman's $r=-0.535, p=0.027$ ) and a positive correlation between the reported frequency of selfie sharing with friends through private messages and extraversion in women (Spearman's $r=0.296, p=0.012$ ) (Table 5).

\subsection{Multivariate Regression Analysis}

On multivariate linear regression analysis with step-wise inclusion of age, gender, and personality traits, the reported frequency of selfie taking was independently negatively correlated to age (beta $=-0.533, \mathrm{p}<0.001$ ) and self-esteem (beta $=-0.206, p=0.020$ ). Similarly, the reported frequency of selfie posting on social media was independently negatively correlated to age (beta $=-0.391, \mathrm{p}<0.001$ ) and self-esteem (beta $=-0.233, p=0.020$ ). The reported frequency of selfie sharing with friends through private messages was independently negatively correlated to age (beta $=-0.480, \mathrm{p}$ $<0.001$ ) and positively correlated to extraversion (beta $=0.264$, $p=0.005)$. The reported frequency of checking the number of likes their selfie received shortly after posting was only independently negatively correlated with age (beta $=-0.337, \mathrm{p}$ $=0.003)$.

Table 3. Correlations by Spearman's correlation coefficient between personality traits and the reported frequency of selfie taking, selfie posting to social media, checking the number of likes their selfie received shortly after posting, and selfie sharing with friends through private messages.

\begin{tabular}{|c|c|c|c|c|}
\hline \multirow{2}{*}{ Personality Trait } & $\begin{array}{c}\text { Selfie Taking } \\
(\mathbf{n}=\mathbf{9 6})\end{array}$ & $\begin{array}{c}\text { Selfie Posting } \\
(\mathbf{n}=\mathbf{8 8})\end{array}$ & $\begin{array}{c}\text { Checking Likes } \\
(\mathbf{n}=\mathbf{7 6})\end{array}$ & $\begin{array}{c}\text { Selfie Sharing } \\
(\mathbf{n}=\mathbf{8 8})\end{array}$ \\
\hline \multirow{2}{*}{ Self-esteem } & $\mathrm{r}=-0.115$ & $\mathrm{r}=-0.165$ & $\mathrm{r}=-0.002$ & $\mathrm{r}=-0.003$ \\
& $\mathrm{p}=0.263$ & $\mathrm{p}=0.125$ & $\mathrm{p}=0.988$ & $\mathrm{r}=0.978$ \\
\hline \multirow{2}{*}{ Extraversion } & $\mathrm{r}=0.145$ & $\mathrm{r}=0.145$ & $\mathrm{r}=0.172$ & $\mathrm{r}=0.218$ \\
& $\mathrm{p}=0.159$ & $\mathrm{p}=0.179$ & $\mathrm{p}=0.137$ & $\mathrm{r}=0.042$ \\
\hline \multirow{2}{*}{ Agreeableness } & $\mathrm{r}=0.153$ & $\mathrm{r}=0.111$ & $\mathrm{p}=0.527$ & $\mathrm{p}=0.148$ \\
& $\mathrm{p}=0.606$ & $\mathrm{p}=0.301$ & $\mathrm{r}=-0.053$ & $\mathrm{r}=-0.148$ \\
\hline \multirow{2}{*}{ Conscientiousness } & $\mathrm{r}=-0.091$ & $\mathrm{r}=0.009$ & $\mathrm{p}=0.651$ & $\mathrm{p}=0.170$ \\
& $\mathrm{p}=0.375$ & $\mathrm{p}=0.936$ & & \\
\hline
\end{tabular}




\begin{tabular}{|c|c|c|c|c|}
\hline Personality Trait & $\begin{array}{c}\text { Selfie Taking } \\
(\mathbf{n}=\mathbf{9 6})\end{array}$ & $\begin{array}{c}\text { Selfie Posting } \\
(\mathbf{n}=\mathbf{8 8})\end{array}$ & $\begin{array}{c}\text { Checking Likes } \\
(\mathbf{n}=\mathbf{7 6})\end{array}$ & $\begin{array}{c}\text { Selfie Sharing } \\
(\mathbf{n}=\mathbf{8 8})\end{array}$ \\
\hline \multirow{2}{*}{ Emotional stability } & $\mathrm{r}=-0.228$ & $\mathrm{r}=-0.238$ & $\mathrm{r}=-0.132$ & $\mathrm{r}=-0.096$ \\
& $\mathbf{p}=\mathbf{0 . 0 2 5}$ & $\mathbf{p}=\mathbf{0 . 0 2 5}$ & $\mathrm{p}=0.257$ & $\mathrm{p}=0.375$ \\
\hline \multirow{2}{*}{ Openness to experiences } & $\mathrm{r}=0.009$ & $\mathrm{r}=0.068$ & $\mathrm{r}=-0.018$ & $\mathrm{r}=-0.023$ \\
& $\mathrm{p}=0.932$ & $\mathrm{p}=0.526$ & $\mathrm{p}=0.874$ & $\mathrm{p}=0.831$ \\
\hline
\end{tabular}

Table 4. Correlations by Spearman's correlation coefficient between personality traits and the reported frequency of selfie taking, selfie posting to social media, checking the number of likes their selfie received shortly after posting, and selfie sharing with friends through private messages according to age stratified as $\leq 25$ and $>25$ years.

\begin{tabular}{|c|c|c|c|c|c|c|c|c|}
\hline & \multicolumn{2}{|c|}{ Selfie Taking } & \multicolumn{2}{|c|}{ Selfie Posting } & \multicolumn{2}{|c|}{ Checking Likes } & \multicolumn{2}{|c|}{ Selfie Sharing } \\
\hline & $\begin{array}{c}\leq 25 \text { years } \\
(n=56)\end{array}$ & $\begin{array}{c}>25 \text { years } \\
(\mathrm{n}=40)\end{array}$ & $\begin{array}{c}\leq 25 \text { years } \\
(\mathrm{n}=56)\end{array}$ & $\begin{array}{c}>25 \text { years } \\
(\mathrm{n}=32)\end{array}$ & $\begin{array}{c}\leq 25 \text { years } \\
(\mathrm{n}=52)\end{array}$ & $\begin{array}{c}>25 \text { years } \\
(\mathrm{n}=24)\end{array}$ & $\begin{array}{c}\leq 25 \text { years } \\
(n=56)\end{array}$ & $\begin{array}{c}>25 \text { years } \\
(\mathrm{n}=32)\end{array}$ \\
\hline Self-esteem & $\begin{array}{l}\mathrm{r}=-0.347 \\
\mathbf{p}=\mathbf{0 . 0 0 9}\end{array}$ & $\begin{array}{l}\mathrm{r}=-0.022 \\
\mathrm{p}=0.893\end{array}$ & $\begin{array}{l}\mathrm{r}=-0.221 \\
\mathrm{p}=0.102\end{array}$ & $\begin{array}{l}\mathrm{r}=-0.179 \\
\mathrm{p}=0.326\end{array}$ & $\begin{array}{l}\mathrm{r}=-0.025 \\
\mathrm{p}=0.859\end{array}$ & $\begin{array}{l}\mathrm{r}=-0.123 \\
\mathrm{p}=0.566\end{array}$ & $\begin{array}{l}\mathrm{r}=-0.123 \\
\mathrm{p}=0.367\end{array}$ & $\begin{array}{l}\mathrm{r}=-0.008 \\
\mathrm{p}=0.964\end{array}$ \\
\hline Extraversion & $\begin{array}{l}\mathrm{r}=0.218 \\
\mathrm{p}=0.106\end{array}$ & $\begin{array}{l}\mathrm{r}=0.023 \\
\mathrm{p}=0.888\end{array}$ & $\begin{array}{l}\mathrm{r}=0.232 \\
\mathrm{p}=0.085\end{array}$ & $\begin{array}{l}\mathrm{r}=-0.011 \\
\mathrm{p}=0.953\end{array}$ & $\begin{array}{l}\mathrm{r}=0.098 \\
\mathrm{p}=0.489\end{array}$ & $\begin{array}{l}\mathrm{r}=0.298 \\
\mathrm{p}=0.157\end{array}$ & $\begin{array}{l}r=0.376 \\
\mathbf{p}=\mathbf{0 . 0 0 4}\end{array}$ & $\begin{array}{l}\mathrm{r}=-0.034 \\
\mathrm{p}=0.852\end{array}$ \\
\hline Agreeableness & $\begin{array}{l}\mathrm{r}=0.165 \\
\mathrm{p}=0.225\end{array}$ & $\begin{array}{l}\mathrm{r}=-0.012 \\
\mathrm{p}=0.942\end{array}$ & $\begin{array}{l}\mathrm{r}=0.146 \\
\mathrm{p}=0.284\end{array}$ & $\begin{array}{l}\mathrm{r}=0.073 \\
\mathrm{p}=0.690\end{array}$ & $\begin{array}{l}\mathrm{r}=0.075 \\
\mathrm{p}=0.598\end{array}$ & $\begin{array}{l}\mathrm{r}=0.121 \\
\mathrm{p}=0.121\end{array}$ & $\begin{array}{l}r=0.363 \\
\mathbf{p}=\mathbf{0 . 0 0 6}\end{array}$ & $\begin{array}{l}\mathrm{r}=-0.106 \\
\mathrm{p}=0.564\end{array}$ \\
\hline Conscientiousness & $\begin{array}{l}\mathrm{r}=0.147 \\
\mathrm{p}=0.304\end{array}$ & $\begin{array}{l}\mathrm{r}=-0.225 \\
\mathrm{p}=0.163\end{array}$ & $\begin{array}{l}\mathrm{r}=0.126 \\
\mathrm{p}=0.284\end{array}$ & $\begin{array}{l}\mathrm{r}=-0.084 \\
\mathrm{p}=0.647\end{array}$ & $\begin{array}{l}\mathrm{r}=-0.020 \\
\mathrm{p}=0.887\end{array}$ & $\begin{array}{l}\mathrm{r}=-0.122 \\
\mathrm{p}=0.569\end{array}$ & $\begin{array}{l}\mathrm{r}=-0.052 \\
\mathrm{p}=0.704\end{array}$ & $\begin{array}{l}\mathrm{r}=-0.240 \\
\mathrm{p}=0.186\end{array}$ \\
\hline Emotional stability & $\begin{array}{l}\mathrm{r}=0.065 \\
\mathrm{p}=0.634\end{array}$ & $\begin{array}{l}\mathrm{r}=-0.293 \\
\mathrm{p}=0.066\end{array}$ & $\begin{array}{l}\mathrm{r}=-0.099 \\
\mathrm{p}=0.467\end{array}$ & $\begin{array}{l}\mathrm{r}=-0.291 \\
\mathrm{p}=0.106\end{array}$ & $\begin{array}{l}\mathrm{r}=0.008 \\
\mathrm{p}=0.955\end{array}$ & $\begin{array}{l}\mathrm{r}=-0.158 \\
\mathrm{p}=0.460\end{array}$ & $\begin{array}{l}\mathrm{r}=0.254 \\
\mathrm{p}=0.059\end{array}$ & $\begin{array}{l}\mathrm{r}=-0.521 \\
\mathbf{p}=\mathbf{0 . 0 0 2}\end{array}$ \\
\hline Openness to experiences & $\begin{array}{l}\mathrm{r}=-0.057 \\
\mathrm{p}=0.675\end{array}$ & $\begin{array}{l}\mathrm{r}=0.061 \\
\mathrm{p}=0.708\end{array}$ & $\begin{array}{l}\mathrm{r}=0.033 \\
\mathrm{p}=0.961\end{array}$ & $\begin{array}{l}\mathrm{r}=0.105 \\
\mathrm{p}=0.568\end{array}$ & $\begin{array}{l}\mathrm{r}=-0.094 \\
\mathrm{p}=0.507\end{array}$ & $\begin{array}{l}\mathrm{r}=0.146 \\
\mathrm{p}=0.495\end{array}$ & $\begin{array}{l}\mathrm{r}=0.007 \\
\mathrm{p}=0.961\end{array}$ & $\begin{array}{l}\mathrm{r}=-0.126 \\
\mathrm{p}=0.492\end{array}$ \\
\hline
\end{tabular}

Table 5. Correlations by Spearman's correlation coefficient between personality traits and the reported frequency of selfie taking, selfie posting to social media, checking the number of likes their selfie received shortly after posting, and selfie sharing with friends through private messages according to gender.

\begin{tabular}{|c|c|c|c|c|c|c|c|c|}
\hline & \multicolumn{2}{|c|}{ Selfie Taking } & \multicolumn{2}{c|}{ Selfie Posting } & \multicolumn{2}{c|}{ Checking Likes } & \multicolumn{2}{c|}{ Selfie Sharing } \\
\cline { 2 - 9 } & $\begin{array}{c}\text { Female } \\
(\mathbf{n}=\mathbf{7 8})\end{array}$ & $\begin{array}{c}\text { Male } \\
(\mathbf{n}=\mathbf{1 8})\end{array}$ & $\begin{array}{c}\text { Female } \\
(\mathbf{n}=\mathbf{7 1})\end{array}$ & $\begin{array}{c}\text { Male } \\
(\mathbf{n}=\mathbf{1 7})\end{array}$ & $\begin{array}{c}\text { Female } \\
(\mathbf{n}=\mathbf{6 5})\end{array}$ & $\begin{array}{c}\text { Male } \\
(\mathbf{n}=\mathbf{1 1})\end{array}$ & $\begin{array}{c}\text { Female } \\
(\mathbf{n}=\mathbf{7 1})\end{array}$ & $\begin{array}{c}\text { Male } \\
(\mathbf{n}=\mathbf{1 7})\end{array}$ \\
\hline \multirow{2}{*}{ Self-esteem } & $\mathrm{r}=-0.151$ & $\mathrm{r}=0.022$ & $\mathrm{r}=-0.207$ & $\mathrm{r}=-0.178$ & $\mathrm{r}=-0.055$ & $\mathrm{r}=0.055$ & $\mathrm{r}=0.034$ & $\mathrm{r}=-0.391$ \\
& $\mathrm{p}=0.187$ & $\mathrm{p}=0.930$ & $\mathrm{p}=0.084$ & $\mathrm{p}=0.495$ & $\mathrm{p}=0.661$ & $\mathrm{p}=0.873$ & $\mathrm{p}=0.778$ & $\mathrm{p}=0.121$ \\
\hline \multirow{2}{*}{ Extraversion } & $\mathrm{r}=0.170$ & $\mathrm{r}=0.104$ & $\mathrm{r}=0.158$ & $\mathrm{r}=0.214$ & $\mathrm{r}=0.092$ & $\mathrm{r}=0.598$ & $\mathrm{r}=0.296$ & $\mathrm{r}=0.017$ \\
& $\mathrm{p}=0.136$ & $\mathrm{p}=0.681$ & $\mathrm{p}=0.187$ & $\mathrm{p}=0.409$ & $\mathrm{p}=0.464$ & $\mathrm{p}=0.052$ & $\mathbf{p}=\mathbf{0 . 0 1 2}$ & $\mathrm{p}=0.949$ \\
\hline \multirow{2}{*}{ Agreeableness } & $\mathrm{r}=0.066$ & $\mathrm{r}=-0.056$ & $\mathrm{r}=0.093$ & $\mathrm{r}=0.081$ & $\mathrm{r}=0.074$ & $\mathrm{r}=0.090$ & $\mathrm{r}=0.160$ & $\mathrm{r}=0.087$ \\
& $\mathrm{p}=0.564$ & $\mathrm{p}=0.824$ & $\mathrm{p}=0.440$ & $\mathrm{p}=0.757$ & $\mathrm{p}=0.559$ & $\mathrm{p}=0.793$ & $\mathrm{p}=0.184$ & $\mathrm{p}=0.741$ \\
\hline \multirow{2}{*}{ Conscientiousness } & $\mathrm{r}=-0.078$ & $\mathrm{r}=-0.212$ & $\mathrm{r}=0.011$ & $\mathrm{r}=-0.007$ & $\mathrm{r}=-0.032$ & $\mathrm{r}=-0.143$ & $\mathrm{r}=-0.167$ & $\mathrm{r}=-0.037$ \\
& $\mathrm{p}=0.500$ & $\mathrm{p}=0.399$ & $\mathrm{p}=0.930$ & $\mathrm{p}=0.979$ & $\mathrm{p}=0.799$ & $\mathrm{p}=0.676$ & $\mathrm{p}=0.165$ & $\mathrm{p}=0.889$ \\
\hline \multirow{2}{*}{ Emotional stability } & $\mathrm{r}=-0.205$ & $\mathrm{r}=-0.263$ & $\mathrm{r}=-0.112$ & $\mathrm{r}=-0.535$ & $\mathrm{r}=-0.062$ & $\mathrm{r}=-0.395$ & $\mathrm{r}=-0.033$ & $\mathrm{r}=-0.334$ \\
& $\mathrm{p}=0.071$ & $\mathrm{p}=0.291$ & $\mathrm{p}=0.352$ & $\mathbf{p}=\mathbf{0 . 0 2 7}$ & $\mathrm{p}=0.623$ & $\mathrm{p}=0.229$ & $\mathrm{p}=0.784$ & $\mathrm{p}=0.190$ \\
\hline \multirow{2}{*}{ Openness to experiences } & $\mathrm{r}=0.008$ & $\mathrm{r}=0.186$ & $\mathrm{r}=0.062$ & $\mathrm{r}=0.366$ & $\mathrm{r}=-0.021$ & $\mathrm{r}=0.352$ & $\mathrm{r}=-0.039$ & $\mathrm{r}=-0.054$ \\
& $\mathrm{p}=0.944$ & $\mathrm{p}=0.459$ & $\mathrm{p}=0.606$ & $\mathrm{p}=0.149$ & $\mathrm{p}=0.870$ & $\mathrm{p}=0.289$ & $\mathrm{p}=0.746$ & $\mathrm{p}=0.836$ \\
\hline
\end{tabular}

\section{DISCUSSION}

In this study, correlations between different personality traits and selfie behaviors were identified in a group of undergraduate psychology students from Romania. Although initially it appeared that individuals with low emotional stability had higher frequencies of selfie taking and posting, this was clearly confounded by the effect of age; since younger individuals appeared to be less emotionally stable and had higher frequency of selfie taking and posting. Lower selfesteem, however, was independently associated with a higher frequency of selfie taking and posting irrespective of age or gender, but the effect was more pronounced in younger individuals for selfie taking. Higher extraversion was also independently associated with a higher frequency of selfie sharing irrespective of age or gender, but the effect was also more pronounced in younger individuals and women. A trend towards higher frequency of selfie sharing was also noted in younger individuals with high agreeableness and in older individuals with lower emotional stability. The frequency of checking for likes after posting selfies to social media was not correlated with any personality traits. These findings shed further light on ongoing investigations studying human characters and their effects on behaviors in an era of digital transformation. 
This study adds uniquely to the research literature when compared to the body of evidence evaluating the association between personality traits and selfie behaviors. As mentioned earlier, the majority of studies only focused on the relationship between selfie behaviors (taking and posting) and narcissism [3 - 8, 10]. Only two main studies evaluated other personality traits and their relationship to selfie behaviors $[6,11]$. In the study by Paris and Pietschnig [11], the authors found an association between the frequency of selfie sharing with friends and higher extraversion, which is in agreement with findings in this current study. However, the authors mainly focused on selfies taken during travel and peculiar behaviors related to the travel environment; thus, this study expands on these findings to confirm the association with selfie sharing in general. The study by Etgar and Amichai-Hamburger [6] evaluated a similar group of undergraduate psychology major students in Israel. They found correlations between several personality traits (self-esteem measured by Rosenberg and Big Five measured by Gosling's Ten-Item Personality Inventory [TIPI]) and the act of selfie taking according to motive (self-approval was negatively related to conscientiousness, emotional stability, openness to experiences, and self-esteem; belonging was related to openness to experiences; documentation was related to agreeableness and extroversion). The use of a different Big Five tool, the wider age range of students, and the focus on selfie taking frequency rather than motive may explain why fewer personality traits were found to have significant correlations in this study compared to the study by Etgar and Amichai-Hamburger [6]. Moreover, the study by Etgar and Amichai-Hamburger did not distinguish between selfie taking and posting or sharing, like was done in this study, and there could be a vast difference in why people take selfies and why they end up posting and sharing them [12].

The negative correlation between self-esteem and the frequency of selfie taking or posting reflects the need to seek self-confirmation from an external source as selfies. If one seeks confidence and approval from others, then one's selfesteem is dependent upon their opinion. This reinforces an earlier finding that people perceive their self-esteem as higher in areas that relate to characteristics that others believe they possess [17]. Studies from other social media platforms also found an association between low-self esteem and the amount of posting information about romantic experiences [18]. The positive correlation between extraversion and selfie sharing matches the notion that extraverts are higher on hedonism and stimulation [19], so when they engage in an activity, they are more likely to share it with others to document their experiences.

The study has some limitations. Not all personality traits could be evaluated in this study and other test tools may be applied in future work such as ones to measure conformity or locus of control. The aim of this study was to evaluate predictive associations rather than causal ones; nonetheless, the effects of residual confounders not accounted for in multivariate analyses cannot be fully dismissed. Moreover, findings from this study may be limited to populations of similar admixture and not necessarily fully generalizable. The study evaluated university students in Romania, and social media behaviors and attitudes may be different in this subpopulation compared to others. Although the age range even for such an undergraduate group was wide and reflected young and middle-aged adults, the sample was primarily composed of women which may have limited the ability to determine gender differences in the evaluated associations.

\section{CONCLUSION}

This study identified a negative correlation between the frequency of selfie taking and posting to social media and selfesteem, while a positive correlation was found between the frequency of selfie sharing with friends through private messages and extraversion. Findings from this study shed more light on consumer behaviors that could inform marketing strategies of digital appliances, social media and digital communication platforms.

\section{LIST OF ABBREVIATIONS}

$$
\begin{aligned}
\text { IPIP-50 = } & \text { International Personality Item Pool-50 scale } \\
\text { TIPI = } & \text { Ten-Item Personality Inventory } \\
\text { HEXACO = } & \text { Honesty-Humility, Emotionality, Extraversion, } \\
& \text { Agreeableness, Conscientiousness, and Openness to } \\
& \text { Experience }
\end{aligned}
$$

\section{ETHICS APPROVAL AND CONSENT TO PARTI- CIPATE}

This study was approved by the ethical committee of the Department of Psychology at Titu Maiorescu University, Romania.

\section{HUMAN AND ANIMAL RIGHTS}

No Animals were used in this research. All human research procedures followed were in accordance with the ethical standards of the committee responsible for human experimentation (institutional and national), and with the Helsinki Declaration of 1975, as revised in 2013.

\section{CONSENT FOR PUBLICATION}

All participants provided written informed consent prior to participation.

\section{AVAILABILITY OF DATA AND MATERIALS}

The datasets used and/or analysed during the current study are available from the corresponding author [A.M.M] on reasonable request.

\section{FUNDING}

None.

\section{CONFLICT OF INTEREST}

The authors declare no conflict of interest, financial or otherwise.

\section{ACKNOWLEDGEMENTS}

The author would like to thank Dr. Alexandru Mihalcea from Titu Maiorescu University for his supervision of the project. 


\section{REFERENCES}

[1] Andone I, Błaszkiewicz K, Eibes M, Trendafilov B, Montag C, Markowetz A. How age and gender affect smartphone usage. 2016. [http://dx.doi.org/10.1145/2968219.2971451]

[2] Milenkovic J. How Much Time Does the Average Person Spend on Their Phone? 2020. Available at: https://kommandotech.com/ statistics/how-much-time-does-the-average-person-spend-on-theirphone/

[3] Weiser EB. \#Me: narcissism and its facets as predictors of selfieposting frequency. Pers Individ Dif 2015; 86: 477-81. [http://dx.doi.org/10.1016/j.paid.2015.07.007]

[4] Halpern D, Valenzuela S, Katz JE. "Selfie-ists" or "Narci-selfiers"?: a cross-lagged panel analysis of selfie taking and narcissism. Pers Individ Dif 2016; 97: 98-101.

[http://dx.doi.org/10.1016/j.paid.2016.03.019]

[5] Wickel TM. Narcissism and social networking sites: The act of taking selfies. Elon J Undergard Res Commun 2015; 6: 5-12.

[6] Etgar S, Amichai-Hamburger Y. Not all selfies took alike: distinct selfie motivations are related to different personality characteristics. Front Psychol 2017; 8: 842.

[http://dx.doi.org/10.3389/fpsyg.2017.00842] [PMID: 28603508]

[7] Barry CT, Doucette H, Loflin DC, Rivera-Hudson N, Herrington LL. "Let me take a selfie": associations between self-photography, narcissism, and self-esteem. Psychol Pop Media Cult 2015; 6: 48-60. [http://dx.doi.org/10.1037/ppm0000089]

[8] Lee JA, Sung Y. Hide-and-seek: Narcissism and "selfie"-related behavior. Cyberpsychol Behav Soc Netw 2016; 19(5): 347-51. [http://dx.doi.org/10.1089/cyber.2015.0486] [PMID: 27028460]

[9] Fox J, Rooney M. The dark triad and trait self-objectification as predictors of men's use and self-presentation behaviours on social networking sites. Pers Individ Dif 2015; 76: 161-5.

[http://dx.doi.org/10.1016/j.paid.2014.12.017]
[10] Sorokowski P, Sorokowska A, Oleszkiewicz A, Frackowiak T, Huk A, Pisanski K. Selfie posting behaviors are associated with narcissism among men. Pers Individ Dif 2015; 85: 123-7.

[http://dx.doi.org/10.1016/j.paid.2015.05.004]

[11] Paris CM, Pietschnig J. But First, Let Me Take a Selfie': Personality Traits as Predictors of Travel Selfie Taking and Sharing Behaviors. 2015. Available at: http://scholarworks.umass.edu/ttra/ttra2015/ Academic_Papers_Oral/1

[12] Katz JE, Crocker ET. Selfies and photo messaging as visual conversation: reports from the United States, United Kingdom and China. Int J Commun 2015; 9: 1861-72.

[13] Rosenberg M. Society and the adolescent self-image. Princeton, NJ: Princeton University Press 1965.

[http://dx.doi.org/10.1515/9781400876136]

[14] Răzvan A, OA M, MT V, DA M, Florea D,CP. Scala de Măsurare a Stimei de Sine a lui Rosenberg Translation ID 404, Universitatea din Bucuresti Available at: http://www.researchcenteral.ro

[15] Goldberg LR. The development of markers for the Big-Five factor structure. Psychol Assess 1992; 4(1): 26-42.

[http://dx.doi.org/10.1037/1040-3590.4.1.26]

[16] Rusu S. P. ML, I. M, D. V, A. SF. Evaluarea personalității din perspectiva modelului Big Five. Date privind adaptarea chestionarului IPIP-50 pe un eșantion de studenți români. Psihol Resur Um 2012; 10(1): $39-56$

[17] MacDonald G, Saltzman JL, Leary MR. Social approval and trait selfesteem. J Res Pers 2003; 37: 23-40.

[http://dx.doi.org/10.1016/S0092-6566(02)00531-7]

[18] Marshall TC, Lefringhausen K, Ferenczi N. The Big Five, selfesteem, and narcissism as predictors of the topics people write about in Facebook status updates. Pers Individ Dif 2015; 85: 35-40. [http://dx.doi.org/10.1016/j.paid.2015.04.039]

[19] Roccas S, Sagiv L, Schwartz SH, Knafo A. The big five personality factors and personal values. Pers Soc Psychol Bull 2002; 28: 789-801. [http://dx.doi.org/10.1177/0146167202289008]

(C) 2020 Alexandra Monica Mihailescu.

This is an open access article distributed under the terms of the Creative Commons Attribution 4.0 International Public License (CC-BY 4.0), a copy of which is available at: https://creativecommons.org/licenses/by/4.0/legalcode. This license permits unrestricted use, distribution, and reproduction in any medium, provided the original author and source are credited. 